\title{
HUBUNGAN TINGKAT PARTISIPASI ANGGOTA KELOMPOK TANI DENGAN DINAMIKA KELOMPOK TANI SERTA PENINGKATAN PRODUKSI PADI DI DESA CINTAMULYA KECAMATAN CANDIPURO KABUPATEN LAMPUNG SELATAN
}

\author{
(Relationship Between Participation Level of Farmer Group Members and Farmer Group Dynamics and the \\ Increase of Rice Production in Cintamulya Village, Candipuro District, South Lampung Regency)
}

Ahmad Miftahuddin, Dewangga Nikmatullah, Kordiyana K Rangga

Jurusan Agribisnis, Fakultas Pertanian, Universitas Lampung, Jl. Prof. Dr. Soemantri Brojonegoro No.1

Bandar Lampung 35141, Telp. 082279716037, e-mail: ahmadmifta520@gmail.com

\begin{abstract}
This study aims to examine participation level of farmer group members, farmer group dynamics, rice production increase, and the relationship between the the participation, group dynamics and rice production increase in Cintamulya Village, Candipuro District, South Lampung Regency. Respondents in this study were 85 farmers. The study was conducted in August - September 2017. The research method used was a survey method using a quantitative descriptive analysis method. The relationship among variables are analyzed using nonparametric statistics Spearman rank correlation test. The results showed that the participation rate of farmer group members is in a low category, group dynamics is in less dynamic category, and increase production is included in a low category. There are significant relationships between the level of participation of members of farmer groups and farmer group dynamics, the level of participation and production increase, and group dynamics and production increase.
\end{abstract}

Key words: group dynamics, production increase, participation

\section{PENDAHULUAN}

Pembangunan sektor pertanian khususnya subsektor tanaman pangan memiliki peran sangat penting dan strategis, hal ini dikarenakan subsektor tanaman pangan memiliki peranan penting dalam menunjang kehidupan sebagian besar penduduk Indonesia. Data PDB Tahun 2015 menunjukkan rata-rata kontribusi tanaman pangan share terbesar kedua setelah tanaman perkebunan yaitu sebesar 3,41 persen dari total share pertanian sebesar 10,28 persen (Kementan 2016).

Komoditas utama tanaman pangan dalam hal ini padi (beras) merupakan bahan pangan pokok bagi sebagian besar penduduk Indonesia. Beras banyak mendapat perhatian, baik ditingkat akademik, politik, maupun masyarakat, mulai dari sistem produksi, distribusi (tataniaga), perdagangan, ekspor, dan impor, disparitas harga, pola konsumsi masyarakat, dinamika pembangunan daerah dan sebagainya (Indah 2015). Sekitar 55 persen konsumsi energi dan 44 persen konsumsi protein penduduk Indonesia berasal dari beras. Dengan pola konsumsi pangan seperti ini, maka kelangkaan beras akan berpengaruh besar terhadap kecukupan gizi penduduk Indonesia (Kementan, 2015).
Menurut BPS (2016), poduksi padi di Provinsi Lampung dalam 6 tahun terakhir mengalami peningkatan. Terdapat 3 daerah sentra produksi padi di Provinsi Lampung, yaitu Kabupaten Lampung Tengah, Kabupaten Lampung Selatan, dan Kabupaten Lampung Timur. Perkembangan produksi padi sawah di Provinsi Lampung menurut kabupaten/kota di tahun 2010-2015 menunjukkan bahwa setelah dihitung dengan menggunakan rumus interval, terdapat tiga kategori tingkatan rata-rata produksi padi yaitu Kabupaten Lampung Tengah dan Kabupaten Lampung Timur termasuk ke dalam kategori tinggi dengan rata-rata produksi sebesar 684.522 ton dan 489.472 ton, Kabupaten Tanggamus dan Kabupaten Lampung Selatan termasuk ke dalam kategori sedang dengan rata rata produksi sebesar 225.928 ton dan 421.593 ton dan kabupaten lainnya termasuk ke dalam kategori rendah.

Berdasarkan data produksi padi sawah yang ada di Provinsi Lampung, Kabupaten Lampung Selatan merupakan salah satu kabupaten yang memiliki katagori potensi pertanian yang sedang, hal tersebut tidak terlepas dari kecamatan yang ikut berkontribusi dalam peningkatan produksi. Menurut BPS (2016) Kecamatan Candipuro merupakan salah satu kecamatan yang menghasilkan produksi padi terbesar kedua 
setelah Kecamatan Palas dengan total produksi padi sebesar 59.564 ton.

Kecamatan Candipuro merupakan salah satu kecamatan yang memiliki kelompok tani terbanyak keempat di Kabupaten Lampung Selatan yakni 307 kelompok tani (poktan) dan 19 kelompok tani berada di Desa Cintamulya dengan total anggota sebanyak 837 orang

Setiap anggota dalam kelompok tani akan berintegrasi, bekerja sama, dan berusaha untuk mencapai tujuan bersama. Semangat anggota tidak selalu berada dalam keadaan statis, tetapi berada dalam keadaan dinamis, yaitu selalu berubah-ubah secara terus menerus yang tercermin ke dalam suatu dinamika kelompok tani. Keberhasilan kelompok dalam melaksanakan usahatani padi dalam banyak hal tentunya terkait dengan dinamika kelompok tani yang bersangkutan. Kelompok yang memiliki dinamika yang baik akan mendukung kelompok dan anggota kelompok tersebut dalam mengambil suatu keputusan dengan benar dan memudahkan pengorganisasian petani dalam penerapan teknologi yang tepat pada setiap tahapan budidaya usahataninya sehingga akan meningkatkan produktivitas (Kartika, Viantimala, dan Nurmayasari 2014)

Menurut Antika, Nikmatullah dan Prayitno (2017), partisipasi aktif dari setiap individu atau kelompok akan menentukan keberhasilan dari pelaksanaan suatu program. Partisipasi anggota dari masing-masing kelompok tani sangat dibutuhkan di setiap kegiatan yang dilakukan oleh suatu kelompok tani agar sesuai dengan tujuan yang ingin dicapai yakni dapat meningkatkan produksi dalam setiap kegiatan usahatani yang dilakukan. Adanya partisipasi anggota dari setiap kelompok tani dapat dilihat bagaimana dinamika yang terbentuk dalam suatu kelompok tani tersebut.

Berdasarkan uraian tersebut, maka tujuan dari penelitian ini adalah untuk mengetahui tingkat partisipasi anggota kelompok tani, tingkat dinamika kelompok tani, peningkatan produksi padi, dan mengetahui hubungan tingkat partisipasi dan dinamika kelompok tani, hubungan partisipasi dengan peningkatan produksi serta hubungan dinamika kelompok tani dengan peningkatan produksi padi di Desa Cintamulya Kecamatan Candipuro Kabupaten Lampung Selatan

\section{METODE PENELITIAN}

Metode penelitian yang digunakan adalah metode survei dengan unit sampel sebanyak 85 responden. Penelitian ini dilakukan di Desa Cintamulya Kecamatan Candipuro Kabupaten Lampung Selatan. Pemilihan lokasi ini ditentukan dengan menggunakan metode purposive sampling yaitu suatu metode penentuan lokasi/sampel penelitian yang disengaja berdasarkan atas pertimbanganpertimbangan tertentu (Sugiarto at.all 2003). Pengambilan data dilakukan pada bulan September 2017. Data yang digunakan dalam penelitian ini adalah data primer dan data sekunder

Metode analisis data yang digunakan pada penelitian ini adalah analisis deskriptif, pengujian hipotesis menggunakan analisis inferensial yakni statistik nonparametrik korelasi Rank Spearman (Siegel 1986). Pengujian hipotesis untuk mengetahui apakah terdapat hubungan antara tingkat partisipasi anggota dengan dinamika kelompok, hubungan antara tingkat partisipasi anggota dengan peningkatan produksi padi, dan hubungan antara dinamika kelompok tani dengan peningkatan produksi.

\section{HASIL PENELITIAN}

\section{A. Gambaran Umum Daerah Penelitian}

Desa Cintamulya memiliki luas wilayah \pm 673 ha yang terdiri dari 4 dusun, yaitu: Dusun Mulyajadi, Dusun II, Dusun Cirebon, dan Dusun Sindang Ayu, dari keempat dusun tersebut memiliki 21 RT. Sektor pertanian khususnya tanaman pangan merupakan penunjang perekonomian terbesar penduduk di Desa Cintamulya dikarenakan sebagian besar profesi masyarakat di Desa Cintamulya merupakan petani padi. Desa Cintamulya memiliki jumlah penduduk 6.389 jiwa pada tahun 2017 yang terdiri dari 3.334 jiwa penduduk laki-laki dan 3.055 jiwa penduduk perempuan.

\section{B. Keadaan Umum Kelompok Tani}

Pembentukan kelompok tani diharapkan mampu menjadi wadah kegiatan di bidang pertanian khususnya usahatani padi dan menjadi pusat proses pertukaran informasi demi kemajuan pertanian di desa tersebut. Anggota kelompok tani selalu melakukan pertemuan untuk membahas kegiatan usahatani di lapang seperti kendala dan hambatan yang sedang dihadapi. Perencanaan kebutuhan 
saprodi Kelompok Tani disusun berdasarkan Rencana Definitif Kebutuhan Kelompok (RDKK).

\section{Keadaan Umum Responden}

\section{Umur responden anggota kelompok tani}

Berdasarkan Tabel 1, hasil penelitian menunjukkan bahwa umur responden berkisar antara 30 -- 68 tahun. Menurut Mantra (2004), kelompok umur 15 -64 tahun termasuk dalam usia produktif. Kondisi rata-rata umur responden adalah 49 tahumn menunjukkan pada kelompok umur usia kerja. Pada usia produktif ini diharapkan anggota kelompok tani memiliki tingkat kemauan, semangat dan kemampuan untuk dapat melaksanakan kegiatan usahatani yang dijalaninya.

\section{Tingkat pendidikan formal anggota kelompok tani}

Berdasarkan penelitian lapang persentase terbesar tingkat pendidikan anggota kelompok tani yang menjadi responden dalam penelitian ini berada pada tingkat sekolah dasar. Hal tersebut dikarenakan anggapan anggota kelompok tani yang menganggap kurang pentingya pendidikan, selain itu juga faktor terbesar ialah dikarenakan kurangnya biaya sekolah.

Tabel 1. Keadaan responden anggota kelompok berdasarkan umur

\begin{tabular}{ccc}
\hline $\begin{array}{c}\text { Interval Umur } \\
\text { (Tahun) }\end{array}$ & $\begin{array}{c}\text { Jumlah } \\
\text { (Jiwa) }\end{array}$ & $\%$ \\
\hline $30--42$ & 20 & 23,53 \\
$43--55$ & 38 & 44,71 \\
$56--68$ & 27 & 31,76 \\
\hline Jumlah & 85 & 100 \\
\hline Rata-rata & 49 & \\
\hline
\end{tabular}

Sumber: Analisis data primer 2017

Tabel 2. Keadaan responden pengurus kelompok tani berdasarkan tingkat pendidikan formal

\begin{tabular}{llc}
\hline $\begin{array}{l}\text { Tingkat } \\
\text { Pendidikan }\end{array}$ & $\begin{array}{l}\text { Jumlah } \\
\text { Formal }\end{array}$ & (Jiwa) \\
\hline SD & 32 & 37,64 \\
SLTP & 22 & 25,88 \\
SLTA & 31 & 36,47 \\
\hline Jumlah & 85 & 100,00 \\
\hline
\end{tabular}

Sumber: Analisis data primer 2017

\section{Tingkat partisipasi anggota kelompok tani}

Partisipasi merupakan suatu bentuk keterlibatan dan keikusertaan aktif dan sukarela karena alasan dari dalam (intrinsik) maupun dari luar (ekstrinsik). Pada Tabel 3 menunjukkan Tingkat partisipasi anggota kelompok tani tergolong dalam klasifikasi tinggi dengan skor rata-rata 377,25. Hasil penelitian lapang menunjukkan nilai interval tertinggi tingkat partsipasi anggota adalah 505,77 dan nilai interval terendah 145,79. Menurut Rangga dkk (2014), partisipasi seseorang yang masuk ke dalam kategori tinggi ialah adanya partisipasi yang aktif dalam kegiatan seperti membuat perencanaan kegiatan, adanya keterlibatan dalam pelaksanaan kegiatan, dan dapat merasakan manfaat dari berpartisipasi pada kegiatan tersebut. Selaras dengan peneltian Rangga, tingkat partisipasi anggota kelompok tani di Desa Cintamulya termasuk ke dalam kategori tinggi dikarenakan adanya keterlibatan anggota kelompok tani dalam setiap kegiatan yang akan dilaksanakan.

Pada kenyataan di lapang, anggota berpartisipasi aktif pada setiap kegiatan maupun pada saat sebelum pelaksanann kegiatan, seperti pada saat adanya perencanaan kegiatan yang dilakukan melalui pertemuan sebagian besar anggota ikut serta, keikutsertaan anggota yang hadir aktif dalam memberikan sumbangan pemikiran berupa pendapat maupun saran. Adanya sumbangan pemikiran dari anggota tersebut menunjukkan bahwa anggota yang ikut serta aktif dalam memberikan masukan terhadap kegiatan yang akan dilaksanakan, sehingga setiap keputusan yang akan diambil bukan hanya dari pemikiran dari pengurus kelompok.

Tabel 3. Klasifikasi variabel tingkat partisipasi anggota kelompok di Desa Cintamulya

\begin{tabular}{cccc}
\hline Klasifikasi & $\begin{array}{c}\text { Interval } \\
\text { (Skor) }\end{array}$ & $\begin{array}{c}\text { Jumlah } \\
\text { sampel }\end{array}$ & $\%$ \\
\hline Sangat Rendah & $145,79-217,77$ & 15 & 17,35 \\
Rendah & $217,78-289,77$ & 18 & 21,18 \\
Sedang & $289,78--361,77$ & 20 & 22,94 \\
Tinggi & $361,78--433,77$ & 21 & 24,41 \\
Sangat Tinggi & $433,78--505,77$ & 12 & 14,12 \\
\hline Jumlah & \multicolumn{3}{l}{85} \\
\hline Mean & $=377,25$ (Tinggi) & & \\
\hline Sumber: Analisis data primer 2017
\end{tabular}

Sumber: Analisis data primer 2017 
Adanya pembagian tugas yang diberikan kepada seluruh anggota yang ada di dalam kelompok tani merupakan salah satu cara agar anggota yang tidak mengikuti pertemuan dapat berpartisipasi aktif dalam kegiatan yang akan dlaksanakan. Saat pelaksanaan kegiatan, terlihat perbedaan antara anggota yang ikut serta di dalam setiap perencanaan yang dilakukan dengan anggota yang tidak ikut serta

Tahap evaluasi dilakukan dengan menilai kesesuaian dan keberhasilan kegiatan yang dilakukan. Kesesuaian antara tujuan yang dibuat dengan kenyataan di lapang, serta hasil yang terlihat merupakan salah satu tolak ukur ada atau tidaknya hasil di dalam suatu kegiatan. Hasil penelitian menunjukkan adanya partisipasi yang aktif dari anggota kelompok tani. Anggota kelompok turut menilai kegiatan yang telah dilakukan dengan adanya evaluasi kegiatan, sehingga secara keseluruhan kegiatan tersebut dapat dilihat sebagai kegiatan kelompok untuk mencapai tujuan bersama yang merupakan tujuan kelompok

\section{Dinamika Kelompok Tani}

Dinamika kelompok berdasarkan pendekatan psikososial antara lain terdiri dari tujuan kelompok, struktur kelompok, fungsi tugas, pembinaan dan pemeliharaan kelompok, kekompakan kelompok, suasana kelompok, tekanan kelompok, keefektivan kelompok dan agenda terselubung. Berdasarkan hasil penelitian nilai atau skor terendah dinamika kelompok tani adalah 331,00 dan nilai atau skor tertinggi adalah $1.430,47$.

Berdasarkan Tabel 4 tingkat kedinamisan kelompok tergolong dalam klasifikasi kurang dinamis dengan skor rata-rata 622,80. Terdapat 15 orang atau sebesar 17,65 persen menempati kelompok pada klasifikasi tidak dinamis, 11 orang atau sebesar 12,94 persen menempati kelompok pada klasifikasi kurang dinamis, 37 kelompok atau sebesar 43,53 persen pada klasifikasi sedang, 9 orang atau sebesar 10,59 persen menempati kelompok pada klasifikasi dinamis, 13 orang atau sebesar 15,29 persen menempati kelompok pada klasifikasi sangat dinamis.

Tingkat kedinamisan yang kurang dinamis pada hasil penelitian ini akan memberikan pengaruh yang kurang positif bagi aktivitas kelompok. Kelompok yang kurang dinamis ini masih harus selalu dibina agar kegiatan yang dilakasankan dapat memberikan pengaruh positif untuk anggota di dalam menjalankan kegiatan usahatani yang dilaksanakan.

Kurangnya pembinaan dan pemeliharaan dalam kelompok menjadikan aktivitas anggota kurang adanya kemajuan di dalam pribadi anggota kelompok seperti edukasi baru tentang usahatani yang mereka laksanakan. Efektivitas kegiatan pun perlu ditingkatkan dalam kelompok. Hal tersebut dikarenakan terdapat beberapa kegiatan yang kurang tepat guna bagi anggota kelompok terlebih lagi di dalam usahatani yang sedang dilaksanakan

\section{E. Peningkatan Produksi Padi}

Produksi merupakan suatu kegiatan yang dikerjakan untuk menambah nilai guna suatu benda atau menciptakan benda baru sehingga lebih bermanfaat dalam memenuhi kebutuhan. Produksi bertujuan untuk memenuhi kebutuhan seseorang untuk mencapai kemakmuran. Kegiatan usahatani yang dilakukan merupakan salah satu upaya meningkatkan kesejahteraan masyarakat di Desa Cintamulya.

Tabel 5 menunjukkan peningkatan produksi yang di hitung dari tahun 2015--2016 bulan Oktober--Desember dan Januari-Maret dan pada tahun 2016-2017 bulan Maret-Mei dan JuliSeptember. Klasifikasi peningkatan produksi padi berada pada klasifikasi sedang dengan rata-rata sebesar 64,70 kg. Hasil penelitian lapang menunjukkan produksi tertinggi adalah $500 \mathrm{~kg}$ dan produksi terendah sebesar $-300 \mathrm{~kg}$. Hasil penelitian tersebut terdapat penurunan produksi yang mengakibatkan nilai produksi menunjukkan nilai negatif.

Tabel 4. Dinamika kelompok pada kelompok tani di Desa Cintamulya Kecamatan Candipuro Kabupaten Lampung Selatan

\begin{tabular}{cccc}
\hline Klasifikasi & Nilai Interval & Jumlah & $\%$ \\
\hline Tidak Dinamis & $331,00-550,89$ & 15 & 17.65 \\
Kurang Dinamis & $550,90-770,79$ & 11 & 12,94 \\
Sedang & $770,80-990,69$ & 37 & 43,53 \\
Dinamis & $990,70-1.210,59$ & 9 & 10,59 \\
Sangat Dinamis & $1.210,60--1.430,49$ & 13 & 15,29 \\
\hline Jumlah & $=622,80$ (Kurang Dinamis) \\
\hline \multicolumn{4}{c}{ Mean } \\
Sumber : Analisis data primer 2017
\end{tabular}

Sumber : Analisis data primer 2017 
Berdasarkan hasil penelitian diketahui bahwa penurunan tersebut diakibatkan karena adanya faktor iklim yakni terjadinya banjir di wilayah desa tersebut. Lahan terendam air yang mengakibatkan rusaknya tanaman padi dan penyediaan kebutuhan usahatani yang tidak sesuai dengan RDKK serta adanya keterlambatan pengiriman pupuk dan tidak sesuainya jumlah pupuk yang dibutuhkan.

\section{F. Pengujian Hipotesis}

Penelitian ini bertujuan untuk melihat hubungan antara variabel tingkat partisipasi anggota kelompok tani dengan dinamika kelompok, hubungan variabel tingkat partisipasi dengan peningkatan produksi serta hubungan variabel dinamika kelompok dengan peningkatan produksi.

Pengujian hipotesis menggunanakn uji korelasi rank sperman untuk melihat hubungan antara variabel yang diteliti dengan melihat berapa besarnya probabilitas untuk memperoleh rs. Kemudian dilanjutkan pengujian hipotesis dengan menghitung rasio kriris/t hitung (Supranto, J. 2000), yang nantinya akan dibandingkan dengan t tabel untuk melihat ada atau tidak hubungan antar variabel yang diteliti. Berdasarkan hasil uji yang dilakukan, terdapat hubungan nyata antara tingkat partisipasi anggota kelompok tani dengan dinamika kelompok, tingkat partisipasi anggota kelompok tani dengan peningkatan produksi padi, serta dinamika kelompok tani dengan peningkatan produksi padi. Pengujian hipotesis dan pembahasan tingkat partisipasi anggota dengan dinamika kelompok tani serta peningkatan produksi padi di Desa Cintamulya Kecamatan Candipuro Kabupaten Lampung Selatan disajikan pada Tabel 6 berikut :

Tabel 5. Peningkatan produksi padi pada kelompok tani di Desa Cintamulya Kecamatan Candipuro Kabupaten Lampung Selatan

\begin{tabular}{cccc}
\hline Klasifikasi & Produksi $(\mathrm{Kg})$ & Jumlah & $\%$ \\
\hline Sangat rendah & $-300--140$ & 5 & 5,58 \\
Rendah & $-141-19$ & 31 & 36,47 \\
Sedang & $20-180$ & 28 & 32,94 \\
Tinggi & $181-341$ & 20 & 23,53 \\
Sangat tinggi & $342-502$ & 1 & 1,18 \\
\hline Jumlah & & 85 & 100 \\
\hline Mean & $=64,70($ sedang) & & \\
\hline Sumber: Analisis data primer 2017
\end{tabular}

\begin{tabular}{|c|c|c|c|c|}
\hline Tabel 6. & $\begin{array}{l}\text { Tingkat } \\
\text { kelompok } \\
\text { kelompok } \\
\text { produksi pa }\end{array}$ & $\begin{array}{l}\text { partisip } \\
\operatorname{tani} \\
\text { ni sel }\end{array}$ & $\begin{array}{l}\mathrm{i} \\
\mathrm{n} \\
\text { pen }\end{array}$ & $\begin{array}{l}\text { anggota } \\
\text { namika } \\
\text { ngkatan }\end{array}$ \\
\hline $\begin{array}{c}\text { Variabel } \\
\text { Bebas }\end{array}$ & $\begin{array}{l}\text { Variabel } \\
\text { Terikat }\end{array}$ & $\begin{array}{c}\text { Koef. } \\
\text { Korelasi } \\
\left(\mathrm{r}_{\mathrm{s}}\right)\end{array}$ & t-tabel & t-hitung \\
\hline $\begin{array}{l}\text { Partisipasi } \\
\text { (X) }\end{array}$ & $\begin{array}{c}\text { Dinamika } \\
\text { Kelompok } \\
\text { (Y1) }\end{array}$ & -.800 & 1,667 & $12.144^{*}$ \\
\hline $\begin{array}{l}\text { Partisipasi } \\
\text { (X) }\end{array}$ & $\begin{array}{l}\text { Peningkatan } \\
\text { Produksi } \\
\text { (Y2) }\end{array}$ & .800 & 1,667 & $12.144 *$ \\
\hline $\begin{array}{l}\text { Dinamika } \\
\text { kelompok } \\
(\mathrm{Y} 1)\end{array}$ & $\begin{array}{l}\text { Peningkatan } \\
\text { Produksi } \\
\text { (Y2) }\end{array}$ & .462 & 1,667 & $4.309 *$ \\
\hline
\end{tabular}

Keterangan :

$\mathrm{r}_{\mathrm{S}} \quad$ : Penduga koefisien korelasi

* : Nyata pada taraf kepercayaan $90 \%(\alpha=0,1, \mathrm{t}$ tabel $=1,667)$

tn : Tidak nyata pada taraf kepercayaan $90 \%(\alpha=0,1, \mathrm{t}$ tabel $=$ $1,667)$

$\mathrm{X} \quad$ : Tingkat partisipasi anggota Kelompok Tani

Y1 : Dinamika Kelompok Tani

Y2 : Peningkatan produksi padi

\section{Hubungan tingkat partisipasi anggota kelompok tani (X) dengan dinamika kelompok tani (Y1) di Desa Cintamulya Kecamatan Candipuro Kabupaten Lampung Selatan}

Berdasarkan hasil pengujian hipotesis menunjukkan hubungan antara variabel partisipasi dengan variabel dinamika kelompok) diketahui berhubungan nyata dengan nilai $\mathrm{t}$ hitung sebesar 12.144. Nilai t hitung lebih besar daripada t tabel yaitu $12.144>1,667$. Hal ini berarti partisipasi anggota kelompok tani berhubungan nyata dengan dinamika kelompok.dengan rs sebesar 80 persen $\left(r_{s}\right.$ $=-0,800)$. Karena nilai rs menunjukkan nilai yang negatif yakni $r s=-800$ artinya apabila tingkat partisipasi anggota kelompok tani meningkat maka dinamika kelompok akan menurun dan begitupun sebaliknya

Mengacu pada teori Neil (2007) yang mengemukakan bahwa hubungan dinamika kelompok dengan tingkat partisipasi adalah bentuk interaksi atau hubungan individu atau seseorang dalam kelompok. Berdasarkan hasil penelitian lapang, saat tingkat partisipasi anggota tergolong tinggi dalam kegiatan, dinamika yang terbentuk kurang dinamis. Hal tersebut dikarenakan salah satunya banyak anggota yang hadir, membuat tidak berjalannya fungsi dan tugas anggota. Selain itu kurangnya pembinaan yang dilakukan kepada anggota menyebabkan dinamika yang terbentuk menurun. 


\section{Hubungan tingkat partisipasi anggota kelompok tani (X) dengan peningkatan produksi (Y2) di Desa Cintamulya Kecamatan Candipuro Kabupaten Lampung Selatan}

Berdasarkan hasil pengujian hipotesis menunjukkan hubungan antara variabel partisipasi dengan variabel peningkatan produksi diketahui berhubungan nyata dengan nilai $\mathrm{t}$ hitung sebesar 12.144. Nilai $t$ hitung lebih besar daripada t tabel yaitu $12.144>1,667$. Hal ini berarti adanya hubungan nyata antara partisipasi anggota kelompok tani dengan peningkatan produksi padi dengan rs sebesar 80 persen $\left(r_{s}=0,800\right)$.

Hubungan dinamika kelompok tani (Y1) dengan peningkatan produksi (Y2) di Desa Cintamulya Kecamatan Candipuro Kabupaten Lampung Selatan

Berdasarkan hasil pengujian hipotesis menunjukkan hubungan antara variabel partisipasi dengan variabel peningkatan produksi diketahui berhubungan nyata dengan nilai $\mathrm{t}$ hitung sebesar 4,309. Nilai t hitung lebih besar daripada t tabel yaitu 4,309 > 1,663. Hal ini berarti adanya hubungan nyata antara dinamika kelompok tani dengan peningkatan produksi padi dengan rs sebesar 46,2 persen $\left(r_{s}=0,462\right)$.

\section{KESIMPULAN}

Tingkat partisipasi anggota kelompok tergolong dalam klasifikasi rendah, tingkat dinamika kelompok pada kelompok tani tergolong dalam klasifikasi sedang, dan klasifikasi peningkatan produksi padi berada pada klasifikasi rendah. Hubungan antara partisipasi dengan dinamika kelompok diketahui berhubungan nyata, partisipasi dan peningkatan produksi diketahui berhubungan nyata, dan partisipasi dengan dinamika kelompok diketahui berhubungan nyata berhubungan nyata.

\section{DAFTAR PUSTAKA}

Antika AY, Nikmatullah D, dan Prayitno RT. 2017. Tingkat partisipasi anggota P3A dalam program pengembangan jaringan irigasi (PJI) di Kelurahan Fajar Esuk Kecamatan Pringsewu Kabupaten Pringsewu. JIIA, 5 (3). 335-343. http://jurnal.fp.unila.ac.id/index. php/JIA/article/view. [10 Juli 2018].

Badan Pusat Statistik. 2016. Luas Panen dan Produksi Padi menurut Kecamatan di
Kabupaten Lampung Selatan. BPS Kabupaten Lampung Selatan.

Indah LSM, Zakaria WA, dan Prasmatiwi FE. 2015. Analisis efisiensi produksi dan pendapatan usahatani padi sawah pada lahan irigasi teknis dan lahan tadah hujan di Kabupaten Lampung Selatan. JIIA, 3 (3). 228-234. http://jurnal.fp.unila.ac.id/ index.php /JIA/article/view. [10 Juli 2018].

Kartika U, Viantimala B, dan Nurmayasari I. 2014. Analisis hubungan dinamika kelompok dengan tingkat penerapan pengelolahan tanaman terpadu (PTT) dan produktivitas usahatani tanaman padi sawah di Desa Palas Aji Kecamatan Palas Kabupaten Lampung Selatan. JIIA, 2 (1). 86-94. http://jurnal.fp. unila.ac.id/index.php/JIA/ article/view. [10 Juli 2018].

Kementrian Pertanian. 2015. Rencana Strategis Kementrian Pertanian 2014-2019. Jakarta. Indonesia

2016. Komoditas Pertanian Sub Sektor Tanaman Pangan. Jakarta. Pusat Data dan Sistem Informasi Pertanian.

Mantra IB. 2004. Demografi Umum. Pustaka Pelajar. Yogyakarta

Neil. 2007. Group Dynamics, Processes and Development. www.wilderdom. com. [15 Juli 2017].

Rangga KK. 2017. The ability of the community in the supporting the local resouce-based productive effort in food self-suffiencient villages of Lampung Province. Proceeding of ISAE International Seminar Bandar Lampung, 10-12 Agustus 2017. Hal 765-770.

Rangga KK dan Syarief YA. 2017. Paddy farmer households' participation and food security level in special effort program in Seputih Raman Sub-district of Central Lampung Regency. IOP Conference Series: Earth and Enviromental Science Vol 142, Hal 1-5.

Rangga KK, Darsono SA, dan Wijaya M. 2014. The participation of micro business affinity group members in the implementation of food self-suffiency action program in Lampung Province. Academic Research International Vol 5(3). Savap Intenational.

Siegel S. 1986. Statistik Non-Parametrik Ilmuilmu Sosial. PT Gramedia Pustaka Utama. Jakarta.

Sugiarto D, Siagian LT, Sunaryanto, dan DS Oetomo. 2003. Teknik Sampling. PT Gramedia Pustaka Utama. Jakarta.

Supranto J. 2000. Statistik Edisi Kelima. Erlangga. Jakarta. 